\title{
The Ypres Salient 1914-1918: historical aerial photography and the landscape of war
}

Birger Stichelbaut ${ }^{1, *}$, Wouter Gheyle ${ }^{2}$, Veerle Van Eetvelde ${ }^{3}$, Marc Van Meirvenne ${ }^{4}$, Timothy Saey ${ }^{4}$, Nicolas Note ${ }^{4}$, Hanne Van den Berghe ${ }^{3} \&$ Jean Bourgeois ${ }^{2}$

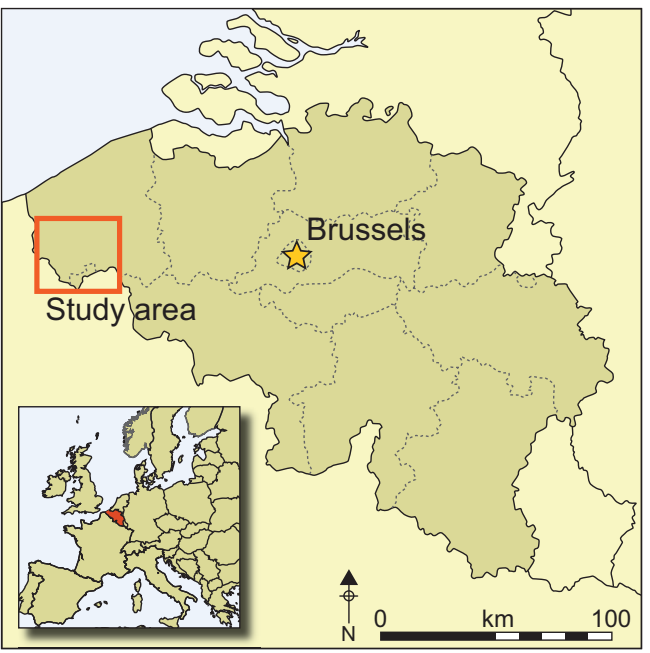

As the centenary commemorations of the Battle of Passchendaele approach, this article is a timely demonstration of how archaeology can provide new insights into the landscape of the Western Front. Assessment of over 9000 aerial photographs taken during the First World War, integrated with other approaches to landscape archaeology, offers a new perspective on the shifting nature of the historic struggle around the town of Ypres in Belgium. The results not only illustrate the changing face of the landscape over that four-year period, but also highlight the potential of aerial photographic records to illuminate hitherto overlooked aspects of landscape heritage.

Keywords: Belgium, First World War, aerial photography, conflict archaeology, landscape

\section{Introduction}

As the final generation of survivors of the First World War has now passed away, the importance of archaeology and the landscape itself as the last remaining witnesses of the conflict is growing rapidly (Chielens 2006; Stichelbaut \& Chielens 2016). The potential of contemporary aerial photography to enable the study of these conflict-marked landscapes and their associated archaeology has already been acknowledged (de Meyer 2006, 2009;

1 Centre for Historical and Archaeological Aerial Photography (In Flanders Fields Museum \& Ghent University), Sint Pietersnieuwstraat 35, Ghent 9000, Belgium

2 Department of Archaeology, Ghent University, Sint Pietersnieuwstraat 35, Ghent 9000, Belgium

3 Department of Geography, Ghent University, Krijgslaan 281 S8, Ghent 9000, Belgium

4 Department of Soil Management, Ghent University, Coupure links 653, Ghent 9000, Belgium

*Author for correspondence (Email: birger.stichelbaut@ugent.be) 
Stichelbaut 2006). Since the origins of 'modern conflict archaeology' at the beginning of the twenty-first century (Saunders 2002), field research on First World War sites and desktop analysis of First World War aerial photographs have become part of mainstream historical archaeology in Flanders (Van Hollebeeke et al. 2014).

Appreciation of the application of historical aerial photographs to archaeology is growing (Cowley \& Stichelbaut 2012; Hanson \& Oltean 2013), and access to archival photographs is being facilitated by means of ongoing digitisation programmes and the development of new discovery aids (Cowley et al. 2013: 21-22). Occasionally, historical photographs are used to document sites of twentieth-century conflict (Gaffney et al. 2004; Kaimaris 2011), but apart from the English Heritage National Mapping Project (Winton \& Horne 2010; Horne 2011), there are few examples of regional-scale implementation for archaeological purposes. Even fewer projects focus on the landscapes of past conflicts (Hegarty et al. 2005; Hegarty \& Newsome 2007; Gheyle et al. 2013; Passmore et al. 2014; Stichelbaut \& Cowley 2016).

The thousands of aerial photographs taken between 1914 and 1918 covering the first $30 \mathrm{~km}$ of the Western Front have already been examined (Stichelbaut 2011). From 2011, we began the exhaustive mapping and analysis of the entire front in Belgium, focusing on the even more challenging conflict landscape near the town of Ypres. The study area includes the Ypres Salient (a bulge in the front line around the town of Ypres), the WijtschateMessines ridge, and the Allied and German hinterland: a region of up to $30 \mathrm{~km}$ wide. The area was the scene of a four-year stalemate in the trenches and witnessed some of the fiercest battles of the First World War. Researchers have initiated mapping projects for heritagemanagement purposes, investigating parts of the Western Front in Belgium by digitising military features identified on contemporary military maps (de Meyer 2005; de Meyer \& Demeyere 2006). Others have used maps to investigate the relationships between trench networks and the terrain (Doyle et al. 2002). This study presents the results of a GISaided mapping project using historical aerial photographs for research at a regional scale. In doing so, we demonstrate the potential for integrating remote-sensing data with aerial photography for the study of recent military landscapes.

The main research goals addressed by this study are: i) investigation of the extent of the First World War battlefields in Belgium; and ii) quantification of their structural components along with their geographic distribution. In addition, the research aims to: iii) examine the diversity of preserved First World War heritage in Belgium across the landscape; iv) determine if there are any differences between the Allied and German sides of the front; and v) explore how landscapes of different periods of the war overlap each other, and how military structures and sites changed as the war progressed.

\section{Study area, historical context and data collection}

After the First Battle of Ypres (19 October-22 November 1914), the front stabilised and both the Allied and German armies entrenched themselves in an arc around Ypres, between 4 and $8 \mathrm{~km}$ away from the town. Unlike the stable Belgian army front to the north (Stichelbaut 2011), several large-scale offensives took place in the Ypres Salient. On 22 April 1915, German troops unleashed the first chlorine gas attack of the war. This marked the start of the Second Battle of Ypres (22 April-25 May 1915) in which the Allies were (C) Antiquity Publications Ltd, 2017 


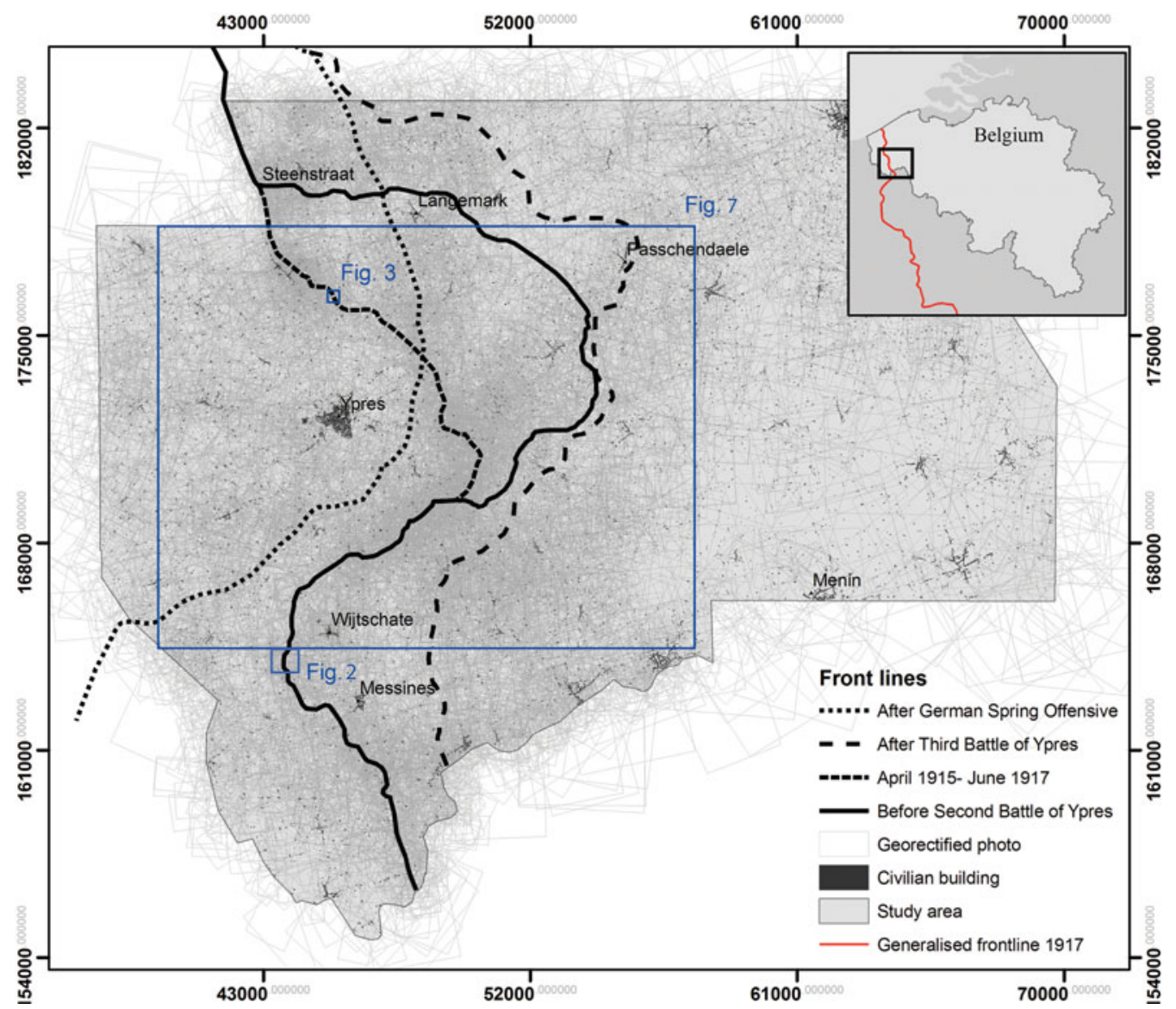

Figure 1. Overview map of the Ypres Salient showing the four major front lines, the area of aerial photographic coverage and the extent covered by Figures 2, 3 and 7.

pushed back $5 \mathrm{~km}$ before digging in again (Edmonds 1928) (Figure 1). During the period between May 1915 and June 1917 there were no major offensives, although at a local scale there were many smaller actions, often aimed at capturing strategic heights. This resulted in numerous minor changes in the position of the front, often by just a couple of hundred metres. An example of such a small-scale battlefield ('Caesar's Nose') is presented as a case study below. On 7 June 1917, the Battle of Messines commenced when 19 deep minesthe effects of which can be seen at the Pool of Peace or Spanbroekmolen crater, for example (Figure 2, bottom) - were simultaneously detonated beneath key positions in the German front line, followed by a large-scale infantry attack (Passingham 1998). As a result, the Wijtschate-Messines Salient was successfully straightened as a prelude to the Third Battle of Ypres (31 July-10 November 1917), which aimed to destroy the German submarine bases along the Belgian coast (Edmonds 1948). In the following months, the rain and continuous artillery fire transformed the battlefields into a shell-pocked, lunar-like landscape. On 10 November 1917, the failed offensive was stopped after the ruins of Passchendaele were captured and both sides dug themselves in again (Figure 1). Just five months later, all Allied 

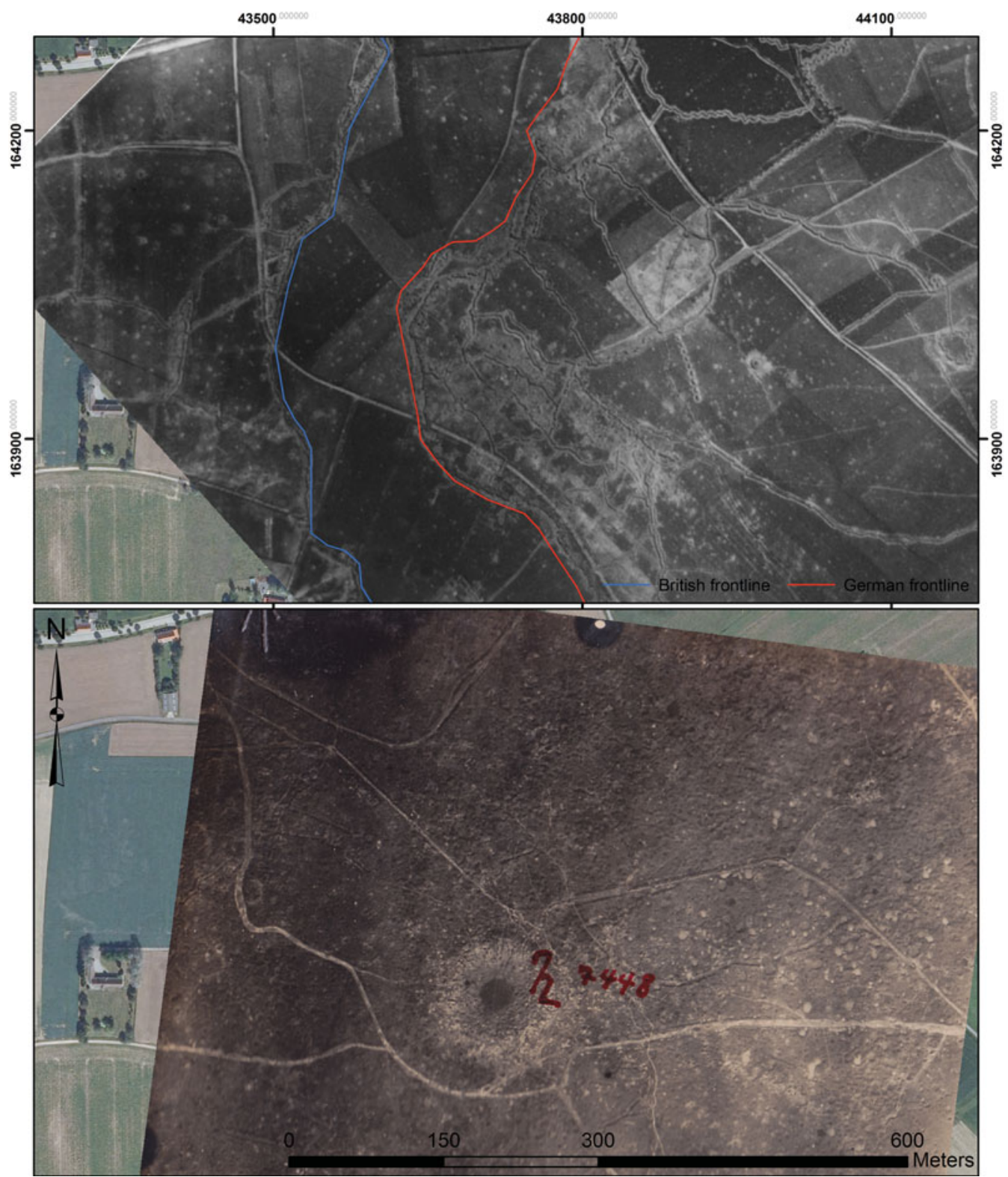

Figure 2. Example comparison of typical aerial photographs. Top: British aerial photograph of Spanbroekmolen (just west of Wijtschate), taken on 1 June 1915 (reproduced by permission of the Imperial War Museum Box Collection, Box 15 B 588). Bottom: same area photographed by a German air crew on 16 September 1918 (reproduced by permission of the In Flanders Fields Museum). The comparison shows the impact of the war on the landscape and the density of features.

gains made in 1917 were relinquished as a result of the German Spring Offensive (9-29 April 1918), which was halted just in front of the town of Ypres. This concise historical overview illustrates the complexity of the Ypres Salient as a stratified, multi-period conflict landscape.

(C) Antiquity Publications Ltd, 2017 
Research in the main archives of historical aerial photographs (Stichelbaut \& Bourgeois 2009) and their subsequent digitisation resulted in a dataset of 9054 near-vertical aerial photographs taken between 30 December 1914 and 14 October 1918 (1914: number of photographs $(\mathrm{n})=1 ; 1915: \mathrm{n}=717 ; 1916: \mathrm{n}=1867 ; 1917: \mathrm{n}=3015 ; 1918: \mathrm{n}=3186$; without date: $n=268$ ), providing a visual and textured record of the progress of the First World War in the study area.

\section{Results and interpretation}

Studying the aerial photographs and the subsequent mapping of visible features resulted in a GIS-dataset of 162417 features (some visible in Figure 3D) that have been interpreted and annotated with metadata (i.e. fields detailing typology, dating and nationality, and photographs used to map the features). The methodology used to map and date the features visible on the aerial photographs has been described in detail by Stichelbaut $(2009,2011)$. The following sections initially focus on a case study in the northern part of the Ypres Salient, explaining the complexity of the war landscape and the need for multi-temporal analysis of the historical remote-sensing data at site level, before moving on to discuss the landscape scale of the research.

\section{Caesar's Nose case study}

The Caesar's Nose study area is located in the northern part of the Ypres Salient on the Pilkem Ridge (Figure 1). On 22 April 1915, during the Second Battle of Ypres, chlorine gas was released between Steenstraat and Langemark. That same evening, the front reached the edge of the study area and the German troops dug in along the higher ridges. An aerial photograph taken on 28 April 1915 shows the hastily dug and disorganised German and French front-line trenches (Figure 3A). On 16 May 1915, French troops launched localised counter-attacks and succeeded in capturing part of the German trench system, which they incorporated into their own field defences ( ${ }^{\mathrm{e}}$ bis Régiment de Marche de Zouaves 1915). As a result, a peculiar bulge was created in the German front line that became known as Caesar's Nose (Figure 3B). This was the start of more than two years of stable trench warfare, accompanied by an expansion of the trench system with more standardised types of firing and communication trenches. On 31 July 1917, the opening day of the Third Battle of Ypres, the area was captured by the $38^{\text {th }}$ Welsh Division (Munby 1920). The front shifted towards Passchendaele, and the function of this former battlefield changed to become a logistical hinterland. An aerial photograph taken in February 1918 shows military huts and roads, while a narrow-gauge railway crosses the landscape to ensure the supply of troops and materials to the front (Figure 3C). The present-day landscape bears almost no surface remains of the First World War with the exception of Caesar's Nose Cemetery (Figure 3D, bottom centre). Today, this cemetery holds the remains of 68 British soldiers who fell during the Third Battle of Ypres. It appears to be isolated on the landscape, and only by looking back at these aerial photographs of the Great War can the reason for its location be understood. The cemetery was located in the former area of no-man's land (see also Figure 3D), which was close to the location where the soldiers fell during the offensive, but, more importantly, was also where an unused open space has survived. 


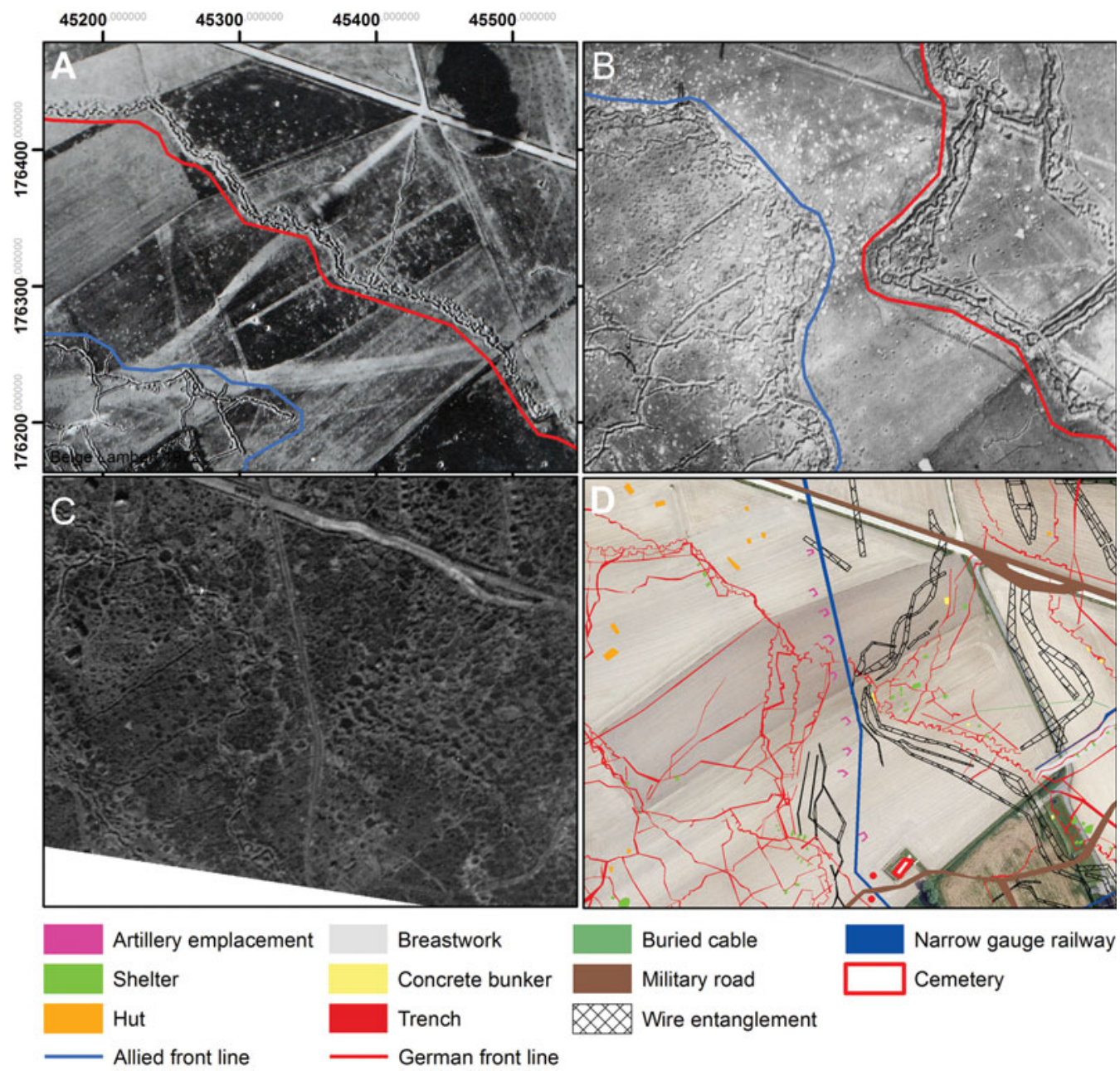

Figure 3. Example of landscape evolution: 'Caesar's Nose' case study. A) Aerial photograph of 28 April 1915 (reproduced by permission of the In Flanders Fields Museum); B) aerial photograph of 14 March 1916 (reproduced by permission of the In Flanders Fields Museum); C) aerial photograph of 21 February 1918 (reproduced by permission of the Imperial War Museum Box Collection 111-9B-249-1918-02-21); D) orthophoto 2014 (AGIV open data) with mapped war features from the beginning to the end of the war.

The mapping of 81 historical aerial photographs available for this site resulted in a plethora of war features. Archaeological excavations of the Allied and German front-line trenches-just $200 \mathrm{~m}$ south to the edge of Figure 3-confirmed the preservation of the trenches and shelters below the surface (Verdegem 2007). This small case study illustrates that the concept of the 'front line' was, to a degree, ephemeral and vague; and from an archaeological perspective, the whole zone is perhaps better regarded as a complex, multilayered conflict landscape. The Ypres Salient comprises a superposition of First World War landscapes: battlefields that had become hinterlands and vice versa. This is in stark contrast (C) Antiquity Publications Ltd, 2017 


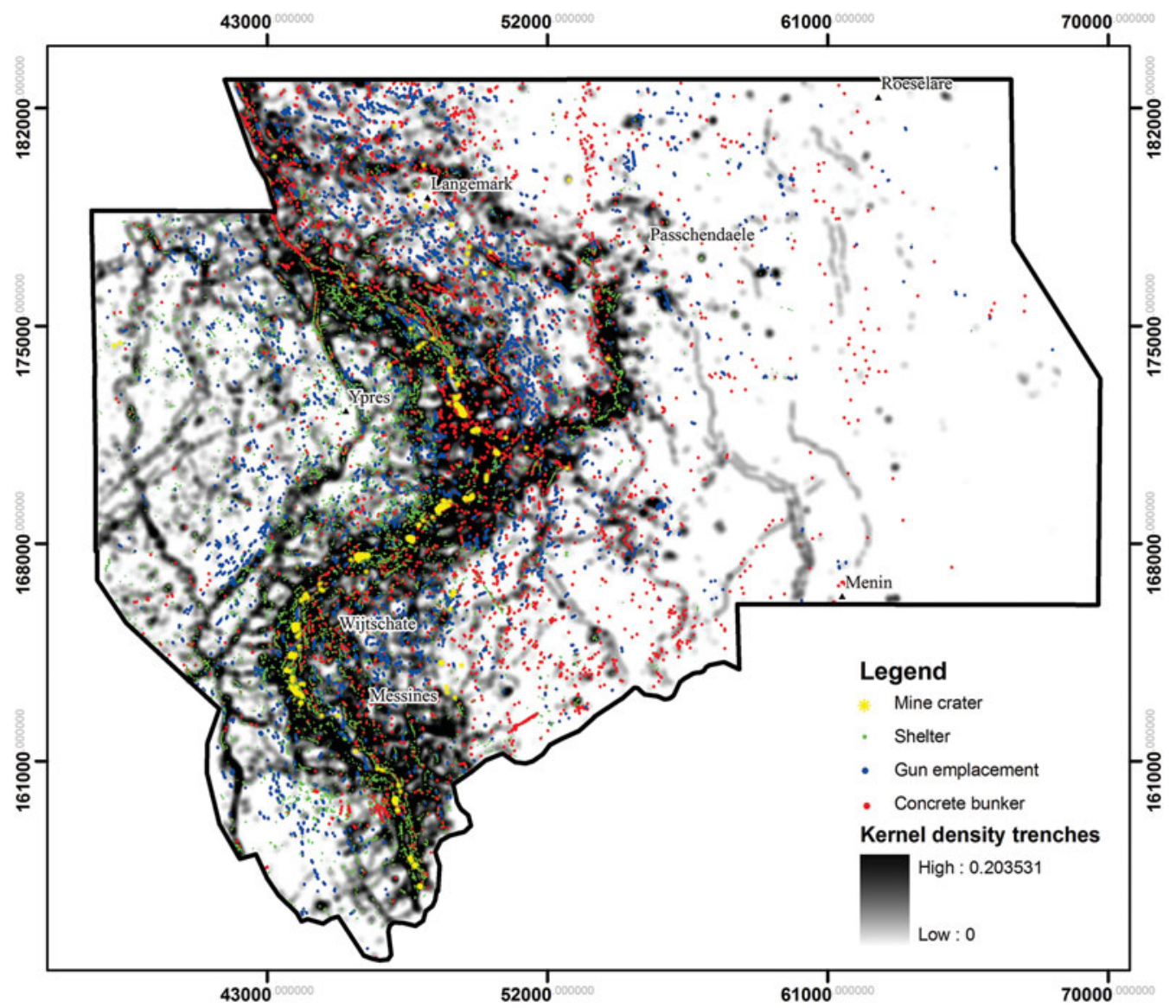

Figure 4. Map of the Ypres Salient with selected features such as mine craters, shelters (light shelters and open-air shelters), gun emplacements and concrete bunkers. Trenches are shown as a kernel density map.

to stable fronts such as the Belgian-German sector between Nieuwpoort and the Ypres Salient (Stichelbaut 2011).

\section{Ypres Salient landscape}

The second level focuses on a broader area of the landscape. The general distribution map (Figures $4 \& 5$ ) and the table (Figure 6) provide a quantitative overview of the density, distribution and diversity of the mapped features in the Ypres Salient over the course of four years of warfare. For the purposes of visualising these maps, a distinction has been made between battlefield features (Figure 4) and hinterland structures (Figure 5), which together make up the multi-temporal conflict landscape of the First World War. The density of mapped features was previously unknown, and points to the industrial extent of the preserved conflict heritage. Although all features are mapped as polygon features, for ease of comparison and overview, they are presented in the table as 'point' features (i.e. bunkers and gun positions), linear features (trenches, railways and the like) and surface features (i.e. 


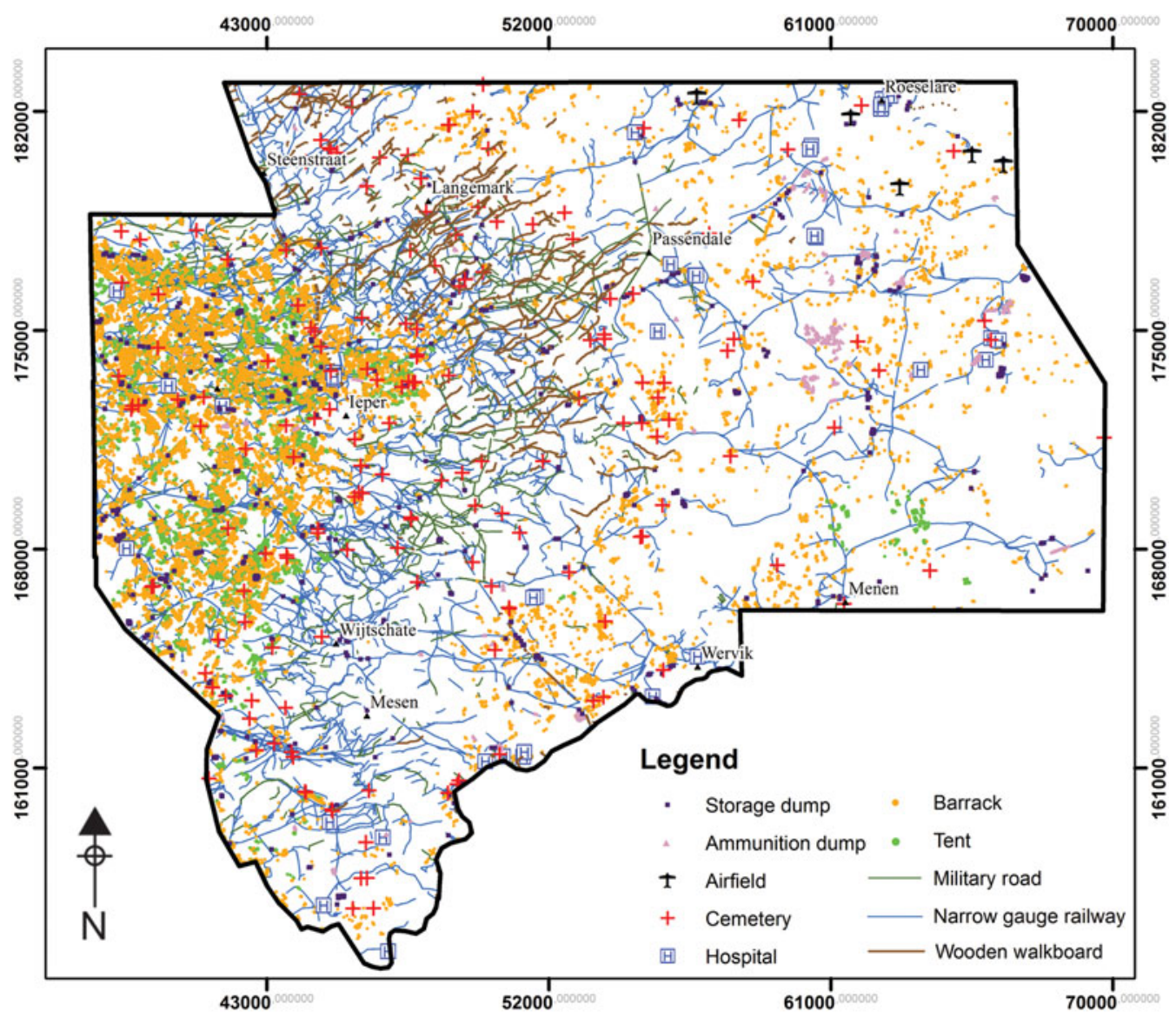

Figure 5. Map of the Ypres Salient with selected hinterland features.

storage depots) (Figure 6). Constraints in the space available here mean that we can only present results for selected categories of features.

\section{Trenches}

The trenches are the first category of military feature, and of these, more than $3500 \mathrm{~km}$ were dug. The density of observed features contrasts sharply with the first $30 \mathrm{~km}$ of the Western Front immediately to the north of this case study area, where only $417 \mathrm{~km}$ have been identified in an area of comparable size (Stichelbaut 2011). The earliest and most basic trenches are foxholes or slit trenches, which were nothing more than a hole in the ground providing cover for an infantryman. From the beginning of positional warfare in October/November 1914, to the start of the Battle of Messines, trenches were the main components of the defensive system and are among the most frequently excavated war remains in Belgium (Dewilde 2006; Dewilde et al. 2007, 2014; Van Hollebeeke et al. 2014; Gheyle et al. 2016). Trench systems comprised a combination of firing trenches, arranged in successive defensive positions, and communication trenches leading towards them. In

(C) Antiquity Publications Ltd, 2017 


\begin{tabular}{|c|c|c|c|c|c|c|c|}
\hline & \multicolumn{3}{|c|}{ Point features (n) } & \multicolumn{2}{|c|}{ Linear features (km) } & \multicolumn{2}{|c|}{ Surface areas (ha) } \\
\hline & Allied & German & Unknown & Allied & German & Allied & German \\
\hline \multicolumn{8}{|l|}{ Trenches } \\
\hline Firing trench & & & & 853.8 & 967.0 & & \\
\hline Communication trench & & & & 809.1 & 867.8 & & \\
\hline Approach trench & & & & 9 & 19.1 & & \\
\hline Fortified shell hole & 285 & 1,003 & & & & & \\
\hline Breastwork & & & & & & 27.1 & 17.3 \\
\hline \multicolumn{8}{|l|}{ Underground mining war } \\
\hline Mine crater & 104 & 115 & 81 & & & & \\
\hline \multicolumn{8}{|l|}{ Bunkers/shelter } \\
\hline Open air shelter & 3,323 & 4,105 & & & & & \\
\hline Light shelter / abri & 6,694 & 2,665 & & & & & \\
\hline Possible light shelter / abri & 81 & 79 & & & & & \\
\hline Concrete bunker & 792 & 1,971 & & & & & \\
\hline Possible concrete bunker & 859 & 1,514 & & & & & \\
\hline Possible deep dugout entrance & 14 & 1 & & & & & \\
\hline \multicolumn{8}{|l|}{ Artillery } \\
\hline Artillery emplacement & 3,099 & 4,202 & & & & & \\
\hline Possible artillery emplacement & 875 & 608 & & & & & \\
\hline \multicolumn{8}{|l|}{ Cemetery } \\
\hline Cemetery & 150 & 112 & & & & & \\
\hline \multicolumn{8}{|l|}{ Transport } \\
\hline Military road & & & & $1,246.0$ & 488.1 & & \\
\hline Narrow-gauge railway & & & & $1,723.7$ & $1,365.4$ & & \\
\hline Walkboard & & & & 124.9 & 55 & & \\
\hline \multicolumn{8}{|l|}{ Logistics } \\
\hline Barrack & 23,947 & 5,299 & & & & & \\
\hline Tent & 25,652 & 555 & & & & & \\
\hline Hospital barrack & 9 & 28 & & & & & \\
\hline Hospital sign (red cross) & 3 & 31 & & & & & \\
\hline Buried cables & & & & 178.2 & 151.5 & & \\
\hline Storage depot & & & & & & 51.7 & 60.9 \\
\hline Ammunition storage & & & & & & 0.1 & 1.7 \\
\hline \multicolumn{8}{|l|}{ Aviation } \\
\hline Airfield & & 5 & & & & & \\
\hline Aircraft shed / tent & & 145.0 & & & & & \\
\hline Balloon shed & & 2 & & & & & \\
\hline Aircraft crash site & & & 5 & 1 & & & \\
\hline \multicolumn{8}{|l|}{ Training landscape } \\
\hline Training trenches & & & & 6.7 & 44.3 & & \\
\hline Artificial shell hole (training) & 8 & 6,114 & & & & & \\
\hline Shooting stand & 7 & 46 & & & & & \\
\hline Obstacle course & 10 & 3 & & & & & \\
\hline Trench track & & & & 0.2 & 1.3 & & \\
\hline \multicolumn{8}{|l|}{ Traditional archaeology } \\
\hline Possible moated site & & & 139 & & & & \\
\hline Moated site & & & 405 & & & & \\
\hline Motte castle & & & 2 & & & & \\
\hline
\end{tabular}

Figure 6. Overview of mapped features organised by functional classes.

mid 1917, the military doctrine changed and defences were organised in greater depth, with concrete bunker strongholds becoming increasingly important. In addition, it was no longer necessary to have uninterrupted trench lines, and these were replaced in many places by short stretches of trenches and shell holes that were used as shelters and transformed into vantage positions for firing (General Headquarters 1918). These shell holes are very 


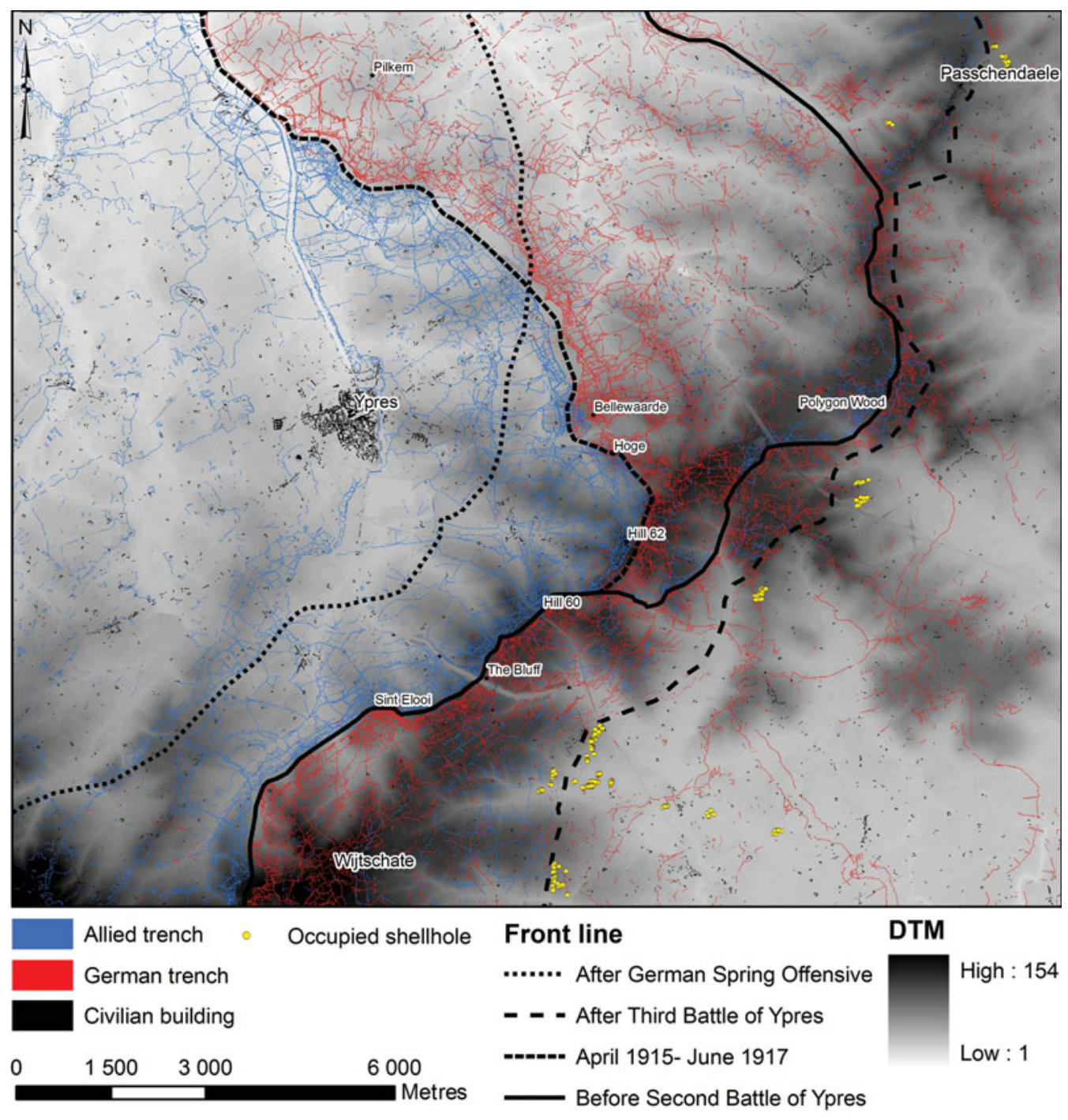

Figure 7. Allied and German trench networks in relation to the topography and main front lines.

difficult to identify, and it is probable that only a small proportion have been identified (Figure 7).

Many typological differences can be noted, but the dominant categories are zigzag trenches (Défense Nationale 1925), which make up 59 per cent of the communication trenches, and trenches with U-shaped traverses (e.g. Stichelbaut \& Chielens 2013: 191), which make up 39.4 per cent of the standard firing trenches. The close relationship between the natural topography of the landscape and the location of the trenches is evident in Figure 7. All the higher ridges are marked by clusters of trenches and were heavily contested places on the landscape. Visual dominance over the enemy's field defences was of the utmost importance, and many places such as Hooge, Bellewaarde, The Bluff and Sint-Elooi became (C) Antiquity Publications Ltd, 2017 
the subject of intensive siege warfare, whereby sappers created tunnels and laid mines in an attempt to gain control of these hot spots (Barton et al. 2004). Within the study area, this resulted in 300 large mine craters (Figure 4; Stichelbaut et al. 2016).

The layout of the trench systems can be seen in Figure 7, which shows the nationality of the mapped trenches. Areas with mixed German and Allied trenches changed hands during offensives, and trench systems of different periods were superimposed upon each other, such as those near Polygon Wood. Even at this overview level, the structure of the trench systems and the extent of the Ypres Salient are evident. Two main fronts can be clearly identified: i) the 'outer Ypres Salient' - the front line prior to the Second Battle of Ypres-comprising a narrow zone of trenches (see for instance Stichelbaut \& Chielens 2013: 60-61, 69), which fits with the military doctrine early in the war wherein "the first line is to be held under all circumstances or retaken immediately in case it should be penetrated by the enemy" (General Headquarters 1918: 6); and ii) the 'inner Ypres Salient' - the most elaborate trench system, which was developed from April 1915 to June 1917 and consisted of several successive positions arranged in great depth (Figure 7). After the Third Battle of Ypres, the trench networks were less extensive. This period is most easily understood by referring to Figure 5 where the whole military infrastructure (i.e. military roads, narrow-gauge railways, and wooden walkboards) are all oriented towards Paaschendaele to support the ongoing offensive. Following this offensive, the Allied trench system is visible as blue trenches in the area between the front lines. In some places, especially close to the German front, organised trenches gave way to occupied and fortified shell holes instead (e.g. Stichelbaut \& Chielens 2013: 203; Figure 7).

As shown by recent geophysical investigations in the study area, the trenches are very well preserved below the surface (Masters \& Stichelbaut 2009; Stichelbaut et al. 2011; Saey et al. 2013, 2016; Dewilde et al. 2014). A case study focusing on four sites in the village of Comines-Warneton in the southern part of the Wijtschate-Messines Salient (covering an area of approximately $28 \mathrm{ha}$ ) showed that nearer the respective fronts, over 79 per cent of the trenches visible on aerial photographs have been preserved (Gheyle et al. 2016).

\section{Bunkers, shelters and dugouts}

Large numbers of constructions close to the trenches, if not incorporated into the parapet, provided varying levels of protection against the weather, shrapnel and even artillery fire. The lightest of these were open-air shelters, merely holes in the ground (Ministère de la Guerre 1916). Light shelters, comprising earthen and wooden-roofed structures, provided better cover. Some have been excavated, but very little remains of them except for some wooden floors (Association for World War Archaeology 2007a \& b). Concrete was used for more solid constructions, such as bunkers and pill boxes. Their spatial distribution was not confined to the front-line area, but they were arranged into defensive positions ranging up to $15 \mathrm{~km}$ deep (Figure $4 \& 7$ ). Strikingly, the greatest number of concrete shelters was recorded on the German part of the front line (Figure 6). This could represent a historical reality, linked to a more defensive military doctrine. On the other hand, the detection of German bunkers was made possible because of heavy artillery fire during the Third Battle of Ypres, which effectively destroyed their camouflage, increasing their visibility on 
aerial photographs. Hundreds of deep dugouts (Barton et al. 2004) provided extensive cover at a depth of 5-15m below the surface (Jones 2010), although only a few entrances have been detected on the aerial photographs because they were small and extensively camouflaged.

\section{Logistical landscape}

In addition to the battlefields and field defences, the aerial photographs and GIS mapping revealed an extensive logistical landscape in which the infrastructure of war that existed to support and maintain the fronts was located and could operate. A large network of narrowgauge railways and military roads ensured the supply of ammunition, building materials and supplies from the areas at the rear towards the front (Figure 5). Troops were not always in the trenches but also spent considerable time in barracks and military camps located at safe distances from the front (Figure 5). Some buildings and tents are identifiable as aid posts or hospital sites. Their location is revealed by red-cross emblems, which were marked on roofs or on the ground to prevent them from being targeted by the artillery. The mapping of huts and barracks reveals a different approach in housing troops near the front. More barracks and huts can be seen on the Allied side than in German territory (Figures 5 \& 6). Temporal analysis has shown that this most probably relates to the build-up of massive numbers of troops due to the Allied 1917 offensives.

The extent of the extensive Allied network of (plank) roads and duckboard tracks leading from Ypres to Passchendaele also relates to the 1917 offensive (Figure 5). The road network, which was built between September 1917 and March 1918, is an indication of the complete destruction of this landscape. The landscape had become so badly destroyed that it was otherwise untraversable. The front line in the crater fields could only be accessed by means of these roads and wooden plank boards. Hundreds of war cemeteries have been detected, showing the extent of a funerary landscape that far exceeds that of the present day. Hundreds of German war cemeteries have also been relocated in the post-war years, and human remains have been reburied in large aggregated cemeteries (Dendooven 2006). The discovery of this hidden and lost aspect of the battlefields opens up perspectives for further anthropological research of these landscapes. Farther away from the front, other sites can be identified, such as exercise trench systems mimicking front-line trenches and the battlefield environment by recreating no-man's land with artificial shell holes. These other hinterland sites include large numbers of ammunition and supply storage dumps and airfields.

\section{Conclusions and future perspectives}

This article is the first to present collated information from more than 9000 historical aerial photographs focusing on one of Belgium's most contested landscapes during the First World War. The sheer number of features mapped points to the industrial level of this military landscape and its associated archaeological heritage. The results of our research show, with unprecedented detail, the spatial extent of this war landscape in Belgium and the distribution of a variety of military features, while the data shows clear differences between (C) Antiquity Publications Ltd, 2017 
the German and Allied landscapes. It also identifies how First World War landscapes of different time periods overlap.

The historical aerial photographic approach adopted here provides an understanding of this landscape and above all indicates where archaeological remains of the First World War might be expected to be found. Many of the mapped war-feature categories have only been archaeologically documented sporadically or sometimes never before. It is still too often the case that investigations into First World War sites are limited to the areas of the battlefields themselves where material remains of the First World War are expected to be found (Van Hollebeeke et al. 2014). This creates a circular argument whereby the focus is all too often on the large density of trenches, while other features in the hinterland areas behind the front are ignored, overlooked or not recognised. The results of this mapping project will provide a robust basis for managing this heritage and a starting point for thematic research focusing in much greater detail on specific categories of war-feature. The aerial photographic approach to the Western Front has the potential to link historical literature sources and narratives to the actual material remains, bridging the gap between history and archaeology, and converting geographic locations into meaningful places.

\section{Acknowledgements}

The authors would like to thank the two anonymous reviewers for their remarks on the content of this paper, and Ghent University (GOA Grant 01G00214), the Walloon government (SPW Subvention 11/49996), the In Flanders Fields Museum and the Province of West-Flanders for each funding parts of this research.

\section{References}

$2^{\mathrm{e}}$ bis Régiment de Marche de Zouaves. 1915. Journal de marche 3 Janvier-31 Juillet 1915. 26 N 837/5. Unpublished document held by the Armée de Terre, France. Available at: http://www.memoiredeshommes.sga.defense.gouv. fr/en/arkotheque/inventaires/ead_ir_consult.php? fam $=3 \&$ ref=6\&le_id=4273 (accessed 11 November 2016).

Association for World War Archaeology. 2007a. Cross roads and Canadian dugouts excavation site. Available at: http://www.a-w-a.be/eng/index2.html (accessed 11 November 2016).

- 2007b. Excavations at Turco Farm. Available at: http://www.a-w-a.be/eng/a19.html (accessed 11 November 2016).

Barton, P., P. Doyle \& J. Vandewalle. 2004. Beneath Flanders Fields: the tunnellers' war 1914-1918. Staplehurst: Spellmount.

Chielens, P. 2006. De Laatste Getuige. Het Landschap meer dan ooit, in P. Chielens, D. Dendooven \& H. Decoodt (ed.) De Laatste Getuige. Het Landschap van Wereldoorlog 1 in Vlaanderen: 9-11. Tielt: Lannoo.
Cowley, D. \& B. Stichelbaut. 2012. Historic aerial photographic archives for European archaeology. European Journal of Archaeology 15: 217-36. http: //dx.doi.org/10.1179/1461957112Y.0000000010

Cowley, D., L. Ferguson \& A. Williams. 2013. The aerial reconnaissance archives: a global aerial photographic collection, in W. Hanson \& I. Oltean (ed.) Archaeology from historical aerial and satellite archives: 13-30. New York: Springer.

Défense Nationale. 1925. Notice sur l'étude des photographies aériennes. Bruxelles: Défense Nationale.

De Meyer, M. 2005. Houthulst and the A19-Project: inventory of World War I heritage based on wartime aerial photography and trench maps, in J. Bourgeois \& M. Meganck (ed.) Aerial photography \& archaeology 2003. A century of information: 87-99. Ghent: Academia.

- 2006. Luchtfoto's uit de Eerste Wereldoorlog: Vroeger en $\mathrm{Nu}$, in P. Chielens, D. Dendooven \& H. Decoodt (ed.) De Laatste Getuige. Het Landschap van Wereldoorlog 1 in Vlaanderen: 143-46. Tielt: Lannoo. 
- 2009. World War 1 battlefields of the Ypres Salient mapped and analysed with aerial photographs. A confrontation with the current landscape and archaeology, in B. Stichelbaut, J. Bourgeois, N. Saunders \& P. Chielens (ed.) Images of conflict. Aerial photography and archaeology: 203-20. Newcastle upon Tyne: Cambridge Scholars.

de Meyer, M. \& F. Demeyere. 2006. De Inventarisatie van de Gemeente Houthulst (prov.

West-Vlaanderen), in De Opbouw van een Archeologisch Beleidsinstrument: 43-74. Brussel: VIOE.

Dendooven, D. 2006. Het Herdenken van de Doden: Begraafplaatsen en Monumenten, in P. Chielens, D. Dendooven \& H. Decoodt (ed.) De Laatste Getuige. Het Landschap van Wereldoorlog 1 in Vlaanderen: 103-10. Tielt: Lannoo.

Dewilde, M. 2006. De Eerste Wereldoorlog en Archeologie, in P. Chielens, D. Dendooven \& H. Decoodt (ed.) De Laatste Getuige. Het Landschap van Wereldoorlog 1 in Vlaanderen: 137-42. Tielt: Lannoo.

Dewilde, M., M. de Meyer \& N. Saunders. 2007. Archeologie van de 'Groote Oorlog'. De Vlaamse Situatie. Monument, Landschappen en Archeologie 26(1): 37-54.

Dewilde, M., B. Stichelbaut, Y. Van Hollebeeke, H. Verboven \& F. Wyffels. 2014. Bellewaarde en zijn turbulent oorlogsverleden. Monument, Landschappen en Archeologie 33(3): 30-47.

Doyle, P., M. Bennett, R. MacLeod \& L. MacKay. 2002. Terrain and the Messines Ridge, Belgium, 1914-1918, in P. Doyle \& M. Bennett (ed.) Fields of battle: terrain in military history: 205-24. London: Kluwer. http://dx.doi.org/10.1007/978-94-017-1550-8_13

Edmonds, E. 1948. History of the Great War. Military operations: France and Belgium, 1917; volume II. $7^{\text {th }}$ June-10 $0^{\text {th }}$ November, Messines and Third Ypres. London: His Majesty's Stationery Office.

Edmonds, J. 1928. History of the Great War based on official documents by direction of the Historical Section of the Committee of Imperial Defence. Military operations. France and Belgium, 1915: volume 1. Winter 1914-15, Battle of Neuve Chapelle, Battle of Ypres. London: Macmillan.

Gaffney, C., J. Gater, T. Saunders \& J. Adcock. 2004. D-Day: geophysical investigation of a World War II German site in Normandy, France. Archaeological Prospection 11: 121-28. http://dx.doi.org/10.1002/arp.233

General Headquarters. 1918. Study and exploitation of aerial photographs. Washington, D.C.: Government Printing Office.
Gheyle, W., R. Dossche, J. Bourgeois, B. Stichelbaut \& V.V. Eetvelde. 2013. Integrating archaeology and landscape analysis for the cultural heritage management of a World War I militarised landscape: the German field defences in Antwerp. Landscape Research 39: 502-22. http://dx.doi.org/10.1080/01426397.2012.754854

Gheyle, W., T. Saey, Y. Van Hollebeeke, S. Verplaetse, N. Note, J. Bourgeois, M. Van Meirvenne, V. Van Eetvelde \& B. Stichelbaut. 2016. Historical aerial photography and multi-receiver EMI soil sensing, complementing techniques for the study of a Great War conflict landscape. Archaeological Prospection 23: 149-64. http://dx.doi.org/10.1002/arp.1534

Hanson, W. \& I. Oltean. 2013. Archaeology from historical aerial and satellite archives. New York: Springer. http://dx.doi.org/10.1007/978-1-4614-4505-0

Hegarty, C. \& S. Newsome. 2007. Suffolk's defended shore. Swindon: English Heritage.

Hegarty, C., S. Newsome \& H. Winton. 2005. The greatest battlefield that never was-Suffolk aerial archaeology. Battlefields Annual Review (2005): 63-71.

Horne, P. 2011. The English Heritage National Mapping Programme, in D. Cowley (ed.) Remote sensing for archaeological heritage management: 144-51. Budapest: Archaeolingua.

JonEs, S. 2010. Underground warfare 1914-1918. Barnsley: Pen \& Sword.

KaImaris, D. 2011. Location of defensive military trenches in central and northern Greece. Archaeological Prospection 18: 223-29. http://dx.doi.org/10.1002/arp.415

Masters, P. \& B. Stichelbaut. 2009. From the air to beneath the soil—revealing and mapping Great War trenches at Ploegsteert (Comines-Warneton), Belgium. Archaeological Prospection 16: 279-85. http://dx.doi.org/10.1002/arp.357

Ministère de la Guerre. 1916. Enseignements tirés de la guerre relatifs à la fortification de campagne juin 1915. Document Allemand Traduit par la S.T.G. Dunkerque: Imprimerie Paul Michel.

Munby, J.E. 1920. A history of the $38^{\text {th }}$ (Welsh) Division. London: Hugh Rees.

Passingham, I. 1998. Pillars of fire. The Battle of Messines Ridge, June 1917. Stroud: Sutton.

Passmore, D., S. Harrison \& D. Capps Tunwell. 2014. Second World War conflict archaeology in the forests of north-west Europe. Antiquity 88: 1275-90. http://dx.doi.org/10.1017/S0003598X00115455 
Saey, T., B. Stichelbaut, J. Bourgeois, V. Van Eetvelde \& M. Van Meirvenne. 2013. An interdisciplinary non-invasive approach to landscape archaeology of the Great War. Archaeological Prospection 20: 39-44. http://dx.doi.org/10.1002/arp.1437

Saey, T., N. Note, W. Gheyle, B. Stichelbaut, J. Bourgeois, V. Van Eetvelde \& M. Van Meirvenne. 2016. EMI as a non-invasive survey technique to account for the interaction between WW I relicts and the soil environment at the Western front. Geoderma 265: 39-52. http://dx.doi.org/10.1016/j.geoderma.2015.11.020

SAUNDERs, N. 2002. Excavating memories: archaeology and the Great War, 1914-2001. Antiquity 76: 101-08. http://dx.doi.org/10.1017/S0003598X00089857

Stichelbaut, B. 2006. The application of First World War aerial photography to archaeology: the Belgian images. Antiquity 80: 161-72. http://dx.doi.org/10.1017/S0003598X00093339

- 2009. World War One aerial photography: an archaeological perspective. Unpublished $\mathrm{PhD}$ dissertation, Ghent University.

- 2011. The first thirty kilometres of the Western Front 1914-1918: an aerial archaeological approach with historical remote sensing data. Archaeological Prospection 18: 57-66. http://dx.doi.org/10.1002/arp.397

Stichelbaut, B. \& J. Bourgeois. 2009. The overlooked aerial imagery of World War One: a unique source for conflict and landscape archaeology. Photogrammetrie - Fernerkundung-Geoinformation 3: 231-40.
Stichelbaut, B. \& P. Chielens. 2013. The Great War seen from the air. In Flanders Fields: 1914-1918. Bruxelles: Fonds Mercator.

- 2016. The aerial perspective in a museum context: above Flanders Fields 1914-1918, in B. Stichelbaut \& D. Cowley (ed.) Conflict landscapes and archaeology from above: 279-91. Farnham: Ashgate.

Stichelbaut, B. \& D. Cowley. 2016. Conflict landscapes and archaeology from above. Farnham: Ashgate.

Stichelbaut, B., T. Saey, F. Meeuws, J. Bourgeois $\&$ M. Van Meirvenne. 2011. World War One heritage in Belgium: combining historical aerial photography and EMI, in D. Cowley (ed.) Remote sensing for archaeological heritage management: 265-73. Budapest: Archaeolingua.

Stichelbaut, B., W. Gheyle, T. Saey, V. Van Eetvelde, M. Van Meirvenne, N. Note, H. Van den Berghe \& J. Bourgeois. 2016. The First World War from above and below. Historical aerial photographs and mine craters in the Ypres Salient. Applied Geography 66: 64-72. http://dx.doi.org/10.1016/j.apgeog.2015.11.020

Van Hollebeeke, Y., B. Stichelbaut \& J. Bourgeois. 2014. From landscape of war to archaeological report: ten years of professional World War I archaeology in Flanders (Belgium). European Journal of Archaeology 17: 702-19. http: //dx.doi.org/10.1179/1461957114Y.0000000065

Verdegem, S. 2007. Caesar's Nose, 1914-1918. Archeologisch Onderzoek van Oorlogspatrimonium langs de Ieperboog. Unpublished MA dissertation, Ghent University.

Winton, H. \& P. Horne. 2010. National Archives for National Survey Programmes: NMP and the English Heritage Aerial Photograph Collection, in D. Cowley, R. Standring \& M. Abicht (ed.) Landscapes through the lens: aerial photographs and the historic environment: 5-18. Oxford: Oxbow. 